

\section{Daftar Isi (Table of Content) Journal of Government
Civil Society}

\begin{tabular}{|c|c|}
\hline \multirow{3}{*}{$1-30$} & $\begin{array}{l}\text { The Application of Social Movement as a Form of Digital Advocacy: Case of } \\
\text { \#TolakRUUPermusikan }\end{array}$ \\
\hline & Muhammad Ananda Alifiarry ${ }^{1}$, Bevaola Kusumasari ${ }^{1}$ \\
\hline & $\begin{array}{l}\left({ }^{1} \text { Department of Public Policy and Management, Faculty of Social and Political Sciences, }\right. \\
\text { Universitas Gadjah Mada, Indonesia) }\end{array}$ \\
\hline \multirow{3}{*}{$31-50$} & $\begin{array}{l}\text { Urban Resilience Strategy in the Climate Change Governance in Makassar } \\
\text { City, Indonesia }\end{array}$ \\
\hline & $\begin{array}{l}\text { Ihyani Malik }{ }^{1} \text {, Andi Luhur Prianto }{ }^{2} \text {, Abdillah Abdillah², Zaldi Rusnaedy }{ }^{3} \text {, } \\
\text { Andi Annisa Amalia }{ }^{4}\end{array}$ \\
\hline & $\begin{array}{l}\text { (' Department of Public Administration, Universitas Muhammadiyah Makassar, Indonesia) } \\
\text { (' Department of Government Studies, Universitas Muhammadiyah Makassar, Indonesia) } \\
\text { ( }{ }^{3} \text { Department of Government Studies, Universitas Pancasakti Makassar, Indonesia) } \\
\text { ( }{ }^{4} \text { Department of Architecture, Faculty of Engineering, Universitas Muhammadiyah } \\
\text { Makassar, Indonesia) }\end{array}$ \\
\hline \multirow{3}{*}{$51-62$} & $\begin{array}{l}\text { Collaboration Governance in The Development of Natural Based Tourism } \\
\text { Destinations }\end{array}$ \\
\hline & 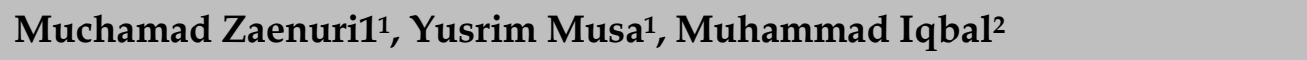 \\
\hline & $\begin{array}{l}\text { (1 Department of Government Affairs and Administration Universitas Muhammadiyah } \\
\text { Yogyakarta, Indonesia) } \\
\text { (2 Department of Political Science National Cheng Kung University, Taiwan, Province of } \\
\text { China) }\end{array}$ \\
\hline \multirow{3}{*}{$63-78$} & $\begin{array}{l}\text { Analysis of Mind Patterns and Work Culture in Government of West } \\
\text { Pasaman District }\end{array}$ \\
\hline & $\begin{array}{l}\text { Sri Andri Yani1 }{ }^{1} \text {, Etika Khairina1, Suswanta1, Mochammad Iqbal } \\
\text { Fadhlurrohman' }\end{array}$ \\
\hline & (' Governmental Studies, Universitas Muhammadiyah Yogyakarta, Indonesia) \\
\hline \multirow{2}{*}{$79-90$} & $\begin{array}{l}\text { The Influence of Social Media (Instagram) of Bantul's General Election } \\
\text { Commissions on Voters Participation in the } 2019 \text { Elections }\end{array}$ \\
\hline & $\begin{array}{l}\text { Agus Priyanto', Eko Priyo Purnomo }{ }^{1,2}{ }^{1} \text {, Mochammad Iqbal } \\
\text { Fadhlurrohman }^{1} \text {, Herry Fahamsyah }{ }^{1} \text {, Etika Khairina }\end{array}$ \\
\hline
\end{tabular}


( ${ }^{1}$ Departement of Government Affairs and Administration, Universitas Muhammadiyah Yogyakarta, Indonesia)

( 2 Jusuf Kalla School of Government, Universitas Muhammadiyah Yogyakarta, Indonesia)

Model Implementation Trap of Policy New Student Acceptance Zoning System in Makassar City

91 - 106 Nuryanti Mustari' ${ }^{1}$, Rudi Hardi' ${ }^{1}$, Amir Muhiddin ${ }^{1}$

$\left({ }^{1}\right.$ Department of Government Studies, Faculty of Social and Political Sciences, Universitas Muhammadiyah Makassar, Indonesia)

Collaborative Urban Governance Model in Environmental Management of Industrial Area

\section{Tri Sulistyaningsih ${ }^{1}$, Saiman', Nofianda Fatimah Azzahra ${ }^{1}$, Nanda}

$107-126$ Adityawan'2, Mohammad Jafar Loilatu ${ }^{3}$

$\left({ }^{1}\right.$ Department of Government Studies, Universitas Muhammadiyah Malang Indonesia) ( ${ }^{2}$ Civil Engineering, Sepuluh Nopember Institute of Technology, Surabaya, Indonesia) $\left({ }^{3}\right.$ Government Affairs and Administration, Universitas Muhammadiyah Yogyakarta, Indonesia)

Towards an Integration of Immigration and Customs Agency in Indonesia: A Step-by-Step Process

\section{7 - $144 \quad$ Ridwan Arifin ${ }^{1}$, Intan Nurkumalawati ${ }^{1}$}

(1 Diploma Program of Immigration Administration, Polytechnic of Immigration, Indonesia) 


\title{
The Application of Social Movement as a Form of Digital Advocacy: Case of \#TolakRUUPermusikan
}

\author{
Muhammad Ananda Alifiarry'1, Bevaola Kusumasari ${ }^{1 *}$ \\ ${ }^{1}$ Department of Public Policy and Management, Faculty of Social and Political Sciences, Universitas \\ Gadjah Mada, Indonesia \\ *Email Correspondence: bevaola@ugm.ac.id
}

\begin{abstract}
Most of the research on social movement and digital advocacy through hashtags is concentrated on the identifications of social media usage. There is limited research concerning the comprehensive understanding and analysis on how it can develop and interact with social networks. This research aims to further identify the process of the successful social movement that has been mobilized by Indonesian's musicians and public by using a hashtag as a form of advocacy in thwarting the Music Draft Bill and in understanding the role of the actors and public engagement behind this social movement. We have analyzed \#TolakRUUPermusikan as a social movement that formed into digital advocacy by referring to the literature review that was conducted by the previous studies. This research will map out the actors and public engagement behind the movement. In each criterion, the result has been aligned with the conceptual framework in application of \#TolakRUUPermusikan as a social movement, the use of online petition as a digital advocacy tool, and the network structure of \#TolakRUUPermusikan to find the actors and understanding the engagements of the public. The implication of this study is to show the success of a social movement to assess policy making and policy failure.
\end{abstract}

Keywords: Policy Formulation, Social Movement, Digital Advocacy, Collective Identity, Music Draft Bill

\begin{abstract}
ABSTRAK
Sebagian besar penelitian tentang gerakan sosial dan advokasi digital melalui tagar terkonsentrasi pada identifikasi penggunaan media sosial. Penelitian kecil mempertimbangkan pemahaman dan analisis yang komprehensif tentang bagaimana hal itu dapat berkembang dan berinteraksi dengan jaringan sosial. Penelitian ini bertujuan untuk lebih mengidentifikasi proses keberhasilan gerakan sosial yang telah dimobilisasi oleh musisi dan masyarakat Indonesia, dengan menggunakan tagar sebagai bentuk advokasi dalam menggagalkan RUU Permusikan dan memahami peran para aktor dan keterlibatan publik di balik gerakan sosial ini. Kami telah menganalisis \#TolakRUUPermusikan sebagai gerakan sosial yang terbentuk menjadi advokasi digital dengan mengacu pada tinjauan literatur yang telah dilakukan oleh penelitian sebelumnya. Penelitian ini akan memetakan aktor dan keterlibatan publik di balik gerakan tersebut. Pada setiap kriteria, hasilnya telah diselaraskan dengan kerangka konseptual dalam penerapan \#TolakRUUPermusikan sebagai gerakan sosial, penggunaan petisi online sebagai alat advokasi digital, serta struktur jaringan \#TolakRUUPermusikan untuk menemukan para pelaku dan memahami keterlibatan para pelaku. masyarakat. Implikasi dari penelitian ini adalah untuk menunjukkan keberhasilan suatu gerakan sosial dalam menilai pembuatan kebijakan dan kegagalan kebijakan.
\end{abstract}

Kata Kunci: Formulasi Kebijakan, Gerakan Sosial, Advokasi Digital, Identitas Bersama, RUU Permusikan

Citation : Alifiarry, M. A., \& Kusumasari, B. (2021). The Application of Social Movement as a Form of Digital Advocacy: Case of \#TolakRUUPermusikan. Journal of Government and Civil Society, 5(1), 1-30. 


\section{INTRODUCTION}

As we know, the development of technology through social media platforms has significantly changed the way people express their aspirations to achieve their rights as a form of freedom of expression. In addition, the development of information and communication technologies has created a wealth of new opportunities by offering connected and open access for users to share and gain information (Johansson \& Scaramuzzino, 2019). The social media platform, Twitter, has increased its role in political discourse as social media has become more popular in many nations. (Bruns \& Burgess, 2011). This political discourse was also used by a coalition, called the Koalisi Nasional Tolak RUU Permusikan (National Coalition to Reject the Music Draft Bill) / KNTL RUUP in creating a social movement on social media to protest the Music Draft Bill that has been released by the House of Representatives in late 2018, in the form of the hashtag \#TolakRUUPermusikan.

Social movements and protests may also have an effect on a broader variety of policy processes, such as agenda-setting, policy initiation, policy formulation, policy implementation, and feedback loops (Silva, 2015). The importance of this is that social movements may have varying policy consequences (Kolb, 2007). The House of Representatives as a policy maker cannot pass a draft law on the basis of the policymaking process carried out by the music ecosystem in Indonesia. The role of the public in this social movement, \#TolakRUUPermusikan, is quite large. It is very interesting to examine how the social movement of this Music Draft Bill attracts the attention of the public and important figures in the music industry, as well as activists of the music protest itself.

This has become an interesting phenomenon. A hashtag that is used as a social movement proves that the internet's growth has created considerable interest in digital platforms. This growth has expanded to include the realm of politics and even has even impacted politics and policy decisions (Chadwick \& Howard, 2009). It was generally accepted that social media was essential to the dissemination of political groups' data and statements (Chadwick A. , 2013). Moreover, social media provides digital advocacy including the use of a hashtag to promote a common cause, sharing information and encouraging supporters (Steinberg, 2016).

It is widely accepted that there are often flaws in public policies. Various explanations have been put forth involving numerous practical and political obstacles intrinsic to their conception and implementation (Fotaki, 2010). In accordance with the existing statements, as the debate on new forms of political participation offered by new digital technologies is thriving (Koc-Michalska, Lilleker, \& Vedel, 2016), most contributions tend to address social media as organizing agents and amplifying vehicles of collective action whose political force unfolds essentially on the streets, such as in the classical examples of the 
Arab Spring, the Indignados, and the Occupy Wall Street movement (Barisione, Michailidou, \& Airoldi, 2017).

Thus, many parties and organizations use a hashtag-based feature to carry out their movements on social media. A hashtag is a short word or phrase that follows the hash or pound sign (\#), such as \#StopDiabetes, \#HIV, or \#MarchforBabies, that is used on social media platforms to brand advocacy movements, archive messages for the movement, and allow those not personally connected to a user to see and comment on messages that use the hashtag (Bruns \& Burgess, 2011). It can be concluded that a growing body of literature has discussed the opportunities that organizations have to advocate for their social movements on social media. Most of these studies, however, only examine the prevalence of social media, or whether organizations use social media for advocacy purposes. Previous studies have barely explained comprehensively how a social movement can thwart a public policy that has been released as a Draft Bill. Research on who the players are, what their position behind the activism is, and how the social movement in a social network can be developed, is a compelling subject.

Given the background of this research, the research questions are the following: "How was the social movement applied in the case of \#TolakRUUPermusikan as a form of digital advocacy? Who are the actors behind \#TolakRUUPermusikan and how does the public engage through this movement?". This study responds to the research by Silva (2015) that highlights social movements and protests that can affect a wider array of political processes including agenda-setting, policy-making, and policy implementation (Silva, 2015). This study shows that a hashtag-based feature can carry out social movements on social media which effects the policy making of the Music Draft Bill by causing its failure. This research is uses the concept of social movements, digital advocacy, and collective identity as an analytical framework. Furthermore, the analysis of this research will focus on the social movement that was made by the public, which was driven by KNTL RUUP, on social media; which effects the policy making of the Music Draft Bill and caused its failure. The role of the public in this movement is quite large, and it is very interesting to examine how a Draft Bill attracts the attention of the public and important figures in the music industry as well as activists of the music draft protest themselves.

The academic and practical implication of this research is to assess the policy framework made by the House of Representatives (DPR RI) relating to the prosperity of the music ecosystem in Indonesia and to provide input for subsequent research both related to artwork and the sustainability of the lives of music activists. This research intensifies the situation with the new evolving policy making that draws several stakeholder personalities, which is the case with the rejection of the Music Draft Bill, by involving the public opinion using the hashtag \#TolakRUUPermusikan. This study also discusses what factors have 
influenced the success of musicians in rejecting the Music Draft Bill, so that the Bill was rejected on April 17th, 2019.

The purpose of this study is to further identify the process of a successful social movement that was mobilized by Indonesian musicians and the public, using a hashtag as a form of advocacy in thwarting the Music Draft Bill and in understanding the role of actors and public engagements behind the social movement. In addition, the purpose of this research is to find out how the impact of \#TolakRUUPermusikan, as a social movement, lead the public opinion to deliver a protest against DPR RI and advocating it through online petition. Lastly, the paper has four parts. First, it reviews the previous relevant academic literature on this case and gives a brief explanation on the context of \#TolakRUUPermusikan. Second, the research methodology and data collection analysis are discussed. Third, the results are analyzed. And fourth, the conclusion is stated and followed by further research attempts.

\section{Social Movement}

Robert \& Kloss (1979) reveal that Antony Giddens defines a social movement as a group of people who are involved in seeking solutions or in hindering a process of social change. The concept of a social movement itself was initially used in the early 19th century, where it retained a very specific meaning, notably: the movement carried out by the new working class, which behaves as a network for non-formal interactions between individuals and groups / organizations engaged in collective action based on a common identity (Sills, 1968; Saunders, 2007). The movement leads to shaping public opinion through its participation in the debate on political and social issues, and the subsequent introduction of some of the ideas of the movement into the mainstream popular perception (Kusumasari \& Kusumaningrum, 2019). Social movements normally exist in conflict with organizations whose objectives and views often conflict and generally arise not long after a situation has been created by social unrest.

The paradigm of this social movement study, from the perspective of classical social psychology, is then reexamined by the new social movement study paradigm. According to this paradigm, the phenomenon of social movements that occurred around 1960 was more appropriate to enter the 1970s. In Europe and America, individual and collective behavior in the various movements that occurred were actions that were no longer a collection of people who behaved irrationally, as understood in the classic paradigm above (Rusmanto, 2012). While new social movements flexibly defined appropriate targets for the continued mobilization of protests, agitation aimed at government institutions remains especially prominent; this represents the significance that continues to be assigned to politics in terms of promoting or stalling social change (Kusche, 2016). 
Currently, we are witnessing the spread of social resistance movements or social movements in an effort to oppose and encourage changes in public policy and change in politics and society in general, both at the local, national, and global levels (Manalu, 2007). In a democratic country, collective action and oppositional political activism are the hallmarks of any society and pose challenges to inequality and exclusion and injustice rooted in people's oppression. They involve political and collective action, resist oppression, and have their own networks (Millward \& Takhar, 2019). Along with the developments in technology and information, the increasingly central role of social media in the contemporary social movement as a form of protest, from the G20 protests to the Arab Spring revolutions and the Occupy Movement to Black Lives Matter, has ignited renewed interest in the temporality of digital protest communication (Poell, 2019).

The intensive use of these medias as networks is said to have shifted the pace and temporal orientation of protest communication, potentially changing how demonstrations are mobilized, maintained, debated, represented and remembered (Barassi, 2015; Kaun, 2016; Merrill \& Lindgren, 2018; Petrick, 2017; Smit, Heinrich, \& Broersma, 2018). Networks not only make a difference in traditional modes of political action; they also make a difference in respect to protests and social movements (Crossley, 2016). With the increasingly prevalent and rapid adoption of social media platforms, and the networks discussed above, more research is beginning to address the intersection of social movements and advocacy functions.

\section{Digital Advocacy in The Form of Protest}

Nowadays, the use of social media has increased rapidly alongside the development of technology. This medium has become a very important modern form of political communication, along with the fact that social media has gained popularity with the possibilities it offers for representatives, organizations, and most importantly, ordinary citizens (Karaduman, 2012). As a key framework for public engagement and community organizing (McNutt, 2011), advocacy encompasses practices and methods such as lobbying, direct mobilization, public education, policy advocacy and coalition building (Almog-Bar \& Schmid, 2014; Dunlop \& Fawcett, 2008; FitzGerald \& McNutt, 1999; Guo \& Saxton, 2014; Jansson, 1994). Terms such as digital advocacy, digital activism, online social movement, cyber activism, and e-advocacy are now springing up in literature (FitzGerald \& McNutt, 1999). For the purposes of this study, the phrase digital advocacy is used to describe social movement tools, tactics and strategies based on conventional activism, which integrate different social media technologies in the context of social movements.

Digital advocacy in professional practice, non-profit organizations and local groups has been slowly taking place over time, with drawbacks as well as advantages of integrating social media technology into advocacy (Dunlop \& Fawcett, 2008; Guo \& Saxton, 2014). 
For example, according to Greenberg \& MacAulay (2009) and Guo \& Saxton (2014), given emerging research on the use of technology for advocacy, non-profit organizations have not used the full potential of social media to their advantage. Ultimately, although some in community mobilization have embraced social media and digital advocacy, many believe that social media platforms have led to greater apathy, often referred to by the term digital slacktivism (Knibbs, 2013). Digital slacktivism leads to a growing movement where individuals use social media for campaigning instead of traditional boots on the ground, organizing and acting (Knibbs, 2013).

Given the evidence that digital advocacy within social work is underused, other research shows that social media platforms, such as Facebook, can be extremely useful for communicating with key stakeholders and for increasing awareness (Guo \& Saxton, 2014; Lovejoy, Waters, \& Saxton, 2012; Waters, Burnett, Lamm, \& Lucas, 2009). Guo and Saxton (2014), for instance, performed an assessment of 188 civil rights and advocacy organizations to see how organizations use Twitter for advocacy objectives, and they found that organizations provide public education, raise awareness, and engage in the building of coalitions and calls for action. Social media platforms also provide opportunities for community building and mobilization as individuals separated by geographical or even socio-political boundaries can show up together in virtual communities and take action through tools, such as online petitions, and mobilize in real time through organized and online protests (Hoefer, 2012; Schoech, 2013).

Thus, before the advent of digital protests, few social movement researchers studied how audiences accessed, interpreted or recognized this communication (Earl \& Rohlinger, Introduction: Media, movements, and political change. , 2012), and this work is seldom carried out, even though it is a common topic of political communication concern. Earl (2015) argues that digital protests have led social movements to examine what new media work has done in so many fields of sociology: it has prompted an increasing rapprochement between sociology and communication (Castells, 2012).

\section{Collective Identity}

As with any social phenomenon, defining collective identity and social movements can be complicated due to the divergence of opinions that exists. From the 1980s onward, movement scholars have increasingly emphasized the importance of collective identity as a factor that stimulates participation in protest (Stelekenburg, 2013). They argued that the generation of a collective identity is vital to the emergence of a movement (Taylor \& Whittier, 1992 ). Collective identity refers to social processes and events not reflecting existing social structures (laws, conventions, and institutions) but emerging in a "spontaneous" sort of way (Imhonopi, Onifade, \& Urim, 2013). 
In many societies, collective behavior and social movements were instrumental in engendering social change, including regime change, and in impacting the policy space. Ginneken (2003) stated that collective identity is an action that is neither conforming (in which actors follow prevailing norms) nor deviant (in which actors violate those norms). The solidity of a collective is essential in determining the success of a social movement (Gamson, 1992). This collective identity is constructed over time as participants come to share their beliefs and begin to see themselves as a collective (Porta \& Diani, 1999; Melucci, 1996).

We live in an era where everything is sophisticated. Services linking to the internet, endorsing people and organizations capable of creating their own media, can initiate the movement itself; this has become crucial. Moreover, a social movement on the part of a relatively large number of people is more or less a persistent and organized effort to bring about or to resist social change (Imhonopi, Onifade, \& Urim, 2013). This concept suggests that the primary goal of a successful social movement is to set the parameters for discourse that surround its cause. Effectiveness throughout this identity would determine the extent to which movements can induce change in their chosen issues (Kusumasari \& Kusumaningrum, 2019). Social movements, on the other hand, a type of collective identity, is a collective action that has purposeful direction and enjoys internal order.

A social media-based movement ultimately involves a focus on inter-collective communication with the public. Social media platforms, as a means of communication, offer a series of separate messages that are organized and fairly short, such as tweets, statuses, photos, or videos that can be easily shared by a collective action on Twitter, Instagram, Facebook, and YouTube (Saxton, Niyirora, Guo, \& Waters, 2015). Aside from that, social media has delivered a new innovation in communication and public interaction. This breakthrough is one of their most innovative instruments, namely hashtags.

\section{The Uses of Hashtag on Digital Advocacy}

As mentioned in the previous paragraph, a hashtag is a tool that significantly facilitates the way the public communicates; a hashtag may signify a topic or theme. Twitter users seek to settle these conflicts as soon as they have been detected - and such efforts often show the value of hashtags as coordination mechanisms: users constantly seek to keep their hashtag free of unwanted or unnecessary distractions, and to optimize the scope of the desired hashtag for all users (Bruns \& Burgess, 2011).

In the early stages of adoption, following the launch of the 2006 hashtag, Twitter had almost none of the extended functionality that it has today. Twitter users were asked to answer the question, "What are you doing?" They followed the accounts of their friends who used 140 characters or less, and little else, to fill their timelines (Burgess, 2011). 
Then, as time went by, the use of hashtags on Twitter developed in mid-2007 by San Francisco-based technologist Chris Messina, both on Twitter itself and in a post on his personal blog, entitled "Groups for Twitter, or a Proposal for Twitter Tag Channels" (Messina, 2007). Messina called his idea a "rather messy proposal" for "improving contextualization, content filtering and exploratory serendipity within Twitter" by creating a system of "channel tags" using the pound or hash (\#) symbol, allowing people to follow and contribute to conversations on particular topics of interest, and it became a very successful innovation; the hashtag's original intended meaning as an "invention" has long since become subverted and exceeded through popular use, largely attributable to its stripped-down simplicity and the absence of top-down regulation around its use. There is no limit or classification system for Twitter hashtags, so all a user needs to do to create or reference one is to type the pound/hash symbol followed by any string of alphanumeric characters (Burgess, 2011).

According to Bruns and Burgess (2011), in the first place, for instance, hashtags can be used to mark tweets relevant to specific known themes and topics; we have already encountered this in the example of the Australian leadership \#spill. They stated that an ad hoc and non-supervised hashtag emergence disadvantage is that competing hashtags may emerge in different regions of the Twittersphere (for example, \#eqnz and \#nzeq for coverage of the 2010 and 2011 Christchurch earthquakes), or that the same hashtag may be used for vastly different simultaneous events (for example, \# spill for the BP oil spill in the Gulf of Mexico in the first half of 2010, as well as the Australian Labor Party leadership challenge).

With the presence of a hashtag, these networks/communities can easily arise in response to emergencies and crises, or they can be more stable, long-term communities of practice or knowledge that develop to spread ideas, news, or opinions on a given topic (Saxton, Niyirora, Guo, \& Waters, 2015). Throughout Indonesia, social movements have formed their hashtags, for example: \#JogjaOraDidol, \#SahkanRUUPKS, \#GagalkanOmnibusLaw, etc.

\section{Case Study: \#TolakRUUPermusikan}

On the August 15, 2018, the DPR RI, under the supervision of the President of the Republic of Indonesia, had created a draft bill regarding music in Indonesia. The bill noted that music, as part of culture, functions as a record of the value of life and the historical footprint of Indonesian civilization which is an important asset in promoting culture that needs to be nurtured, preserved and developed; that at present times, there are still problems in the music scene, related to the implementation, protection, data collection, and filing so that a comprehensive arrangement can be done, in order for the music to develop continuously and to provide benefits for the progress of the nation; that 
the existing laws and regulations have not been able to fulfill legal developments and community dynamics so that a legal umbrella is needed that can achieve good governance and provide legal certainty; that, based on considerations of the draft bill on August 15, 2018, referred to in letter a, letter b, and letter c, it is necessary to form a law on the regulation (Dewan Perwakilan Rakyat Indonesia, 2018).

The draft bill, namely RUU Permusikan, as of August 15, 2018, which was circulated amongst the public, was a proposed idea initiated by DPR RI, that hailed from BKD DPR RI (Afifiyah, 2019). Furthermore, this draft was then suggested officially by the legislative body of DPR RI as an initiative of DPR RI in the yearly meeting of DPR RI on the October 2, 2018; and DPR RI aimed to finish the draft before their end of commission, which falls on the October 1, 2019 (Afifiyah, 2019).

However, since the draft law was submitted by the Indonesian Parliament, it garnered a very massive yet varying response from music activists in Indonesia. For instance, various top musicians such as Cholil Mahmud, from the band Efek Rumah Kaca and Danilla Riyadi, made a coalition called: Koalisi Nasional Tolak RUU Permusikan / KNTLRUUP (National Coalition Rejecting the Bill). More than 250 prominent musicians also took part in the coalition. In general, this bill contains articles that overlap with several existing laws, such as Copyright Law, Handover Act on Print and Record Works, and ITE Law (Perwitasari, 2019).

The Indonesian music scene currently still has problems regarding the implementation, protection, data collection, archiving, and the well-being of musicians. The low welfare of musicians is partly due to the fact that music is not considered a profession, which implies that there are no standard fees or insurance. The Music Bill contains several articles that are considered controversial and at least 19 articles that were problematic. Starting from editorial obscurity or the sound of the article, the obscurity of "who" and "what" is regulated, to the fundamental problem of guaranteeing freedom of expression in music. Some problematic articles were criticized by the KNTLRUUP, including articles 4, 5, 7 , 10, 11, 12, 13, 15, 18, 19, 20, 21, 31, 32, 33, 42, 49, 50, and 51 (Perwitasari, 2019). However, the most controversial articles are articles 5, 18, 19, 32, 42, and 50. Article 5 contains the prohibition of musicians from committing violence and breaking the law, making pornographic content, provoking conflicts between groups and degrading human dignity. Musicians view this article as shackling freedom of expression and creativity. Article 18 contains the involvement of a music promoter in every music show which must have a license. This article is considered problematic for independent music performances. Article 19 contains the obligation to involve Indonesian musicians as companions in every musical performance from abroad. This article does not consider that not all musicians from abroad are willing to co-exist with local musicians. Article 32 contains the need for musicians to conduct competency tests to be recognized as a music actor profession, which of course is 
seen as hampering a musician's career. Article 42 contains the obligation of entertainment business actors to provide traditional music where it is deemed that not all entertainment venues are suitable for playing traditional music. Article 50 regulates imprisonment and fines for violations of Article 5. These controversial articles can hinder the creativity of musicians in Indonesia and it is from these conditions that various rejection of the Music Bill have emerged.

According to an article written by Cholil Mahmud, the notions that unite musicians before the Draft Law on Draft Law (RUU-P) are articles on the restraint of freedom of expression in article 4 paragraph 1, article 5, and article 50 (Mahmud, 2019). Many agreed, including Cholil Mahmud, that freedom of expression is absolute, according to the mandate of the 1945 Constitution article 28 and article 3 of the Culture Promotion Act. The musicians, who are members of the KNTLRUUP, have also analyzed academic manuscripts and draft bills, and they have dissected articles per article, and they have finally stated their refusal.

This reason was also revealed by Cholil Mahmud through his article, as one of the members joined in the coalition; this draft law could potentially curb freedom of expression. He found the Draft Bill had another face, namely regulation on certification, licensing and musical competence. It contains articles that discussed topics of certification, licenses and competencies for musicians. However, not only the arrangement was in context, but the discussion from article to article was quite systematic, in-depth, comprehensive and tended to stray too far. On the other hand, the articles that regulated other music activities, such as the process of creation, reproduction, distribution and consumption, were only discussed as needed, not considered profound and seen as if they were a supplement, or additional attachments (Mahmud, 2019).

Anang Hermansyah, a national musician and member of the Indonesian House of Representatives Commission 10, announced to formally withdraw the proposed draft bill at the Indonesian Parliament's Legislation Body (Baleg), on March 9, 2019, which was only two days before the National Music Day (Wardhani, 2019). Anang stated that this step was carried out in response to input and responses from all parties involved in the very massive music industry in Indonesia (Wardhani, 2019). Finally, on June 17, 2019, the Music Draft Bill was thwarted from the list of the House of Representative's (DPR RI') Priority National Legislation Program (Prolegnas).

\section{RESEARCH METHOD}

This study utilized a case study method to develop an in-depth analysis of the social movement process by the public on social media, which effected the policy making of Music Draft Bill into failure by a social movement, namely \#TolakRUUPermusikan. The context of this study stresses the development of technology in social networking as a 
social movement and the appraisal of a Music Draft Bill that has been labeled as a policy failure. The role of the public in this social movement process was quite large, and it was very interesting to examine how the social movement process of this music bill attracted the attention of the public and many figures in the music industry, as well as activists of the music who refused so that this Draft Bill was canceled. A lot of social movements in Indonesia take the form of hashtags, as a form of digital advocacy, such as: \#SahkanRUUPKS or \#GagalkanOmnibusLaw. To date, however, these movements have still not succeeded in bringing the policy down from the House of Representative's (DPR RI) priority legislation agenda and in making it a policy failure.

The research was undertaken using two methods at its heart, namely social network analysis and qualitative content analysis. The researcher chooses a multi-method analysis approach; it has been argued that mixed methods research can be useful in nursing and health science because of the complexity of the phenomena studied (Ostlund, Kidd, Wengstrom, \& Rowa-Dewar, 2010). In addition, using a specific case will help the researcher to investigate a real-life phenomenon in a comprehensive way (Yin, 2009). Social network analysis (SNA) is now widely used in the field of online research, particularly in social media such as Twitter, Instagram, and Facebook. SNA is becoming an important tool for investigators, but all the necessary information is often available in a distributed environment (Ghali, Panda, Hassanien, Abraham, \& Snasel, 2012).

The first method undertaken to assess the role of social media, such as Twitter, is to perform social network analysis in social movements. The process uses Gephi language programming framework for text analysis. Twitter is a relatively recent platform for social networking, providing researchers with rich data to explore a multitude of issues. Released as a networking tool in 2006 that would enable users to let friends know what they were up to, Twitter quickly assumed an expanded role. The research would use the hashtag "\#" for an advanced search in the content post because this symbol is used to analyze the social movement on the topic we focused on. The study did a network mapping with the data, that was collected from Twitter, which can provide valuable information about the presence of the users in this \#TolakRUUPermusikan. Metadata, which was carried out from social media networks, revealed information about individual participants and their connection, which can be assessed by the number and nature of connected actions (Himelboim, Smith, Rainie, Shneiderman, \& Espina, 2017). Mapping the relationships of the message regarding a certain issue allows the identification of users who are part of highly connected subnetworks or clusters (Himelboim, McCreery, \& Smith, 2013).

In order to do such mapping networking and to deepen the study of the actor's role in pursuing this movement through social media, this study will analyze the hashtag \#TolakRUUPermusikan as the main source of observing data. The timeframe used by the author in analyzing this movement is from February 1, 2019, to February 7, 2019. In data 
retrieval performed by the author, the tool used is Twint. This tool that is created to crawl from tweets on Twitter, and tweets can be taken based on the username or keywords that have been determined, and the keywords used are: \#TolakRUUPermusikan; with a total of 8,834 tweets in a week. After the process of retrieving data through Twint, Pandas API is a tool used in the Python programming language that is useful for carrying out data manipulation and analysis processes.

This happens because each line that has many mentions or hashtags, is made into each line that contains only one mention or hashtag. Then with this Pandas API, the username is used as a source in the visualization of the "network" and mentions and hashtags as the target. Then Tableau Desktop becomes a software for data analysis and reporting. Tableau, in the form of a desktop application, can present visualizations (Wesley, Eldridge, \& Terlecki, 2011). Gephi also becomes a tool for visualizing social network analysis and for calculating "centrality measurements" of the data that has been taken (Cherven, 2015).

This study also uses a word cloud to deepen the research. A word cloud is a kind of weighted list to visualize language or text data, which gains increasing attention and more application opportunities as the big data time approaches (Jin, 2017). In order to do the research, the researcher was using a software, named Orange 3 to do the mapping. Moreover, those phases, as supporting data, contributed to helping the researcher sort out the words that often appear as a form of social movement to the Music Draft Bill itself.

\section{FINDINGS AND DISCUSSION Application of \#TolakRUUPermusikan as a Social Movement}

While some users used the hashtag shortly after its phenomenon, Twitter-related activity increased over time with the \#TolakRUUPermusikan. More people got involved, and as time progressed, more tweets were sent. This activity developed in peaks of tweet volumes, which became more frequent in later movement stages (Figure 2). The increasing number of hashtag users suggests that engagement with this movement has been sustained over time among an increasingly wide user base, while inflating activity suggests that this social movement has been driven by attention bursts. 
Table 1. List of Actors Who Brought \#TolakRUUPermusikan in the Beginning

\begin{tabular}{|c|c|c|c|c|c|c|}
\hline No & $\begin{array}{c}\text { Date } \\
\text { of } \\
\text { Tweet }\end{array}$ & Username & Role & $\begin{array}{l}\text { Retweets } \\
\text { and } \\
\text { Comments }\end{array}$ & Likes & Content of Tweet \\
\hline 1 & $\begin{array}{l}\text { Jan } \\
29^{\text {th }} \\
2019\end{array}$ & @sayahanyazakie & $\begin{array}{c}\text { Non- } \\
\text { verified } \\
\text { user }\end{array}$ & 1 & 0 & $\begin{array}{l}\text { \#TolakRUUPermusikan } \\
\text { (quoting a tweet } \\
\text { regarding RUU } \\
\text { Permusikan from } \\
\text { @TirtoID) }\end{array}$ \\
\hline 2 & $\begin{array}{l}\text { Jan } \\
30^{\text {th }} \\
2019\end{array}$ & $@$ Thebrandals & $\begin{array}{l}\text { Verified } \\
\text { user / } \\
\text { Band }\end{array}$ & 56 & 22 & $\begin{array}{l}\text { "Selamat datang di era } \\
\text { fasisme baru } \\
\text { \#TolakRUUpermusikan" }\end{array}$ \\
\hline 3 & $\begin{array}{l}\text { Jan } \\
31^{\text {st }} \\
2019\end{array}$ & $@$ @omikazer & $\begin{array}{l}\text { Artist / } \\
\text { Illustrator }\end{array}$ & $1.2 \mathrm{~K}$ & 458 & $\begin{array}{l}\text { Gua sebagai penikmat \& } \\
\text { pendengar musik } \\
\text { menolak RUU } \\
\text { permusikan. Gua gak } \\
\text { mau selera musik gua } \\
\text { diatur \& ditentukan oleh } \\
\text { pemerintah. RUU } \\
\text { Permusikan juga rentan } \\
\text { akan pasal karet yang } \\
\text { bisa mengkriminalisasi } \\
\text { musisi dan pekerja seni } \\
\text { \#TolakRUUPermusikan }\end{array}$ \\
\hline 4 & $\begin{array}{l}\text { Feb } \\
4^{\text {th }} \\
2019\end{array}$ & $@$ TirtoID & $\begin{array}{l}\text { Mass } \\
\text { Media }\end{array}$ & 307 & 250 & $\begin{array}{l}\text { Ketika berita ini ditulis, } \\
\text { petisi } \\
\text { \#TolakRUUPermusikan } \\
\text { telah ditandatangani } \\
\text { oleh hampir } 130 \text { ribu } \\
\text { akun. Selain 'serangan } \\
\text { udara', para musisi juga } \\
\text { menyatakan pendapat } \\
\text { secara langsung di } \\
\text { Cilandak Town Square, } \\
\text { Jakarta Selatan, } \\
\text { (4/2/2019). }\end{array}$ \\
\hline & & & & & & https://tirto.id/dfSi \\
\hline
\end{tabular}

Looking at the beginnings of the \#TolakRUUPermusikan social movement itself, it can be seen in Table 1 that it started on January 29, 2019, stated by ordinary people who have less power than public figures or official accounts in general with the account name: 
@sayahanyazakie. This fact shows that this hashtag, \#TolakRUUPermusikan, is original because the keywords used in this hashtag are purely from public unrest, and this is also not a hashtag whose keywords were agreed upon by a collective movement such as the KNTL RUUP, public figures, or even musicians themselves who were clearly affected. Usually, as a movement forms into hashtag, they will discuss it first the keyword itself before the hashtag is introduced to the public and goes viral. Meanwhile, it is precisely the well-known accounts such as public figures, musicians and the collective KNTL RUUP (who have driven its case by this hashtag) who emerged after the existence of this organic hashtag, which was then moved together to turn this case into a form of protest. We may conclude that this account, @sayahanyazakie, became the first originator of the keyword “Tolak RUU Permusikan," which was ultimately used by the public to protest the released Music Draft Bill.

In addition to the phenomenon that has been described earlier in this chapter, \#TolakRUUPermusikan eventually developed into a social movement and was used by the public and musicians to deliver their protest on Twitter, followed by this hashtag. This hashtag was well mobilized and \#TolakRUUPermusikan had enlivened the traffic on Twitter from February 1, 2019, to February 7, 2019. This social movement succeeded in getting many actors involved in delivering their aspirations during that time period. In the end, they were also able to influence their followers on Twitter from replies, likes, and retweets, making the engagement of \#TolakRUUPermusikan viral.

\section{The Traffic of \#TolakRUUPermusikan on Twitter}

Even though the hashtag was first seen on January 29, 2019, and it finished its role as a movement on June 17, 2019, the research found a specific time period of this movement that really made a change to this policy. In this section, supported by the data provided from February 1 to February 7, it is shown in Figure 1 that the greatest number of tweets was recorded on February 4, 2019. However, how those tweets translate into interaction with other accounts or people needs to be analyzed through engagement number. Engagement shows the number of every provided means of interaction on a Tweet (Simply Measured, 2014). Formula of tweet engagement is defined as:

$\Sigma$ engagement $=\Sigma($ replies + retweets + likes $)$ 


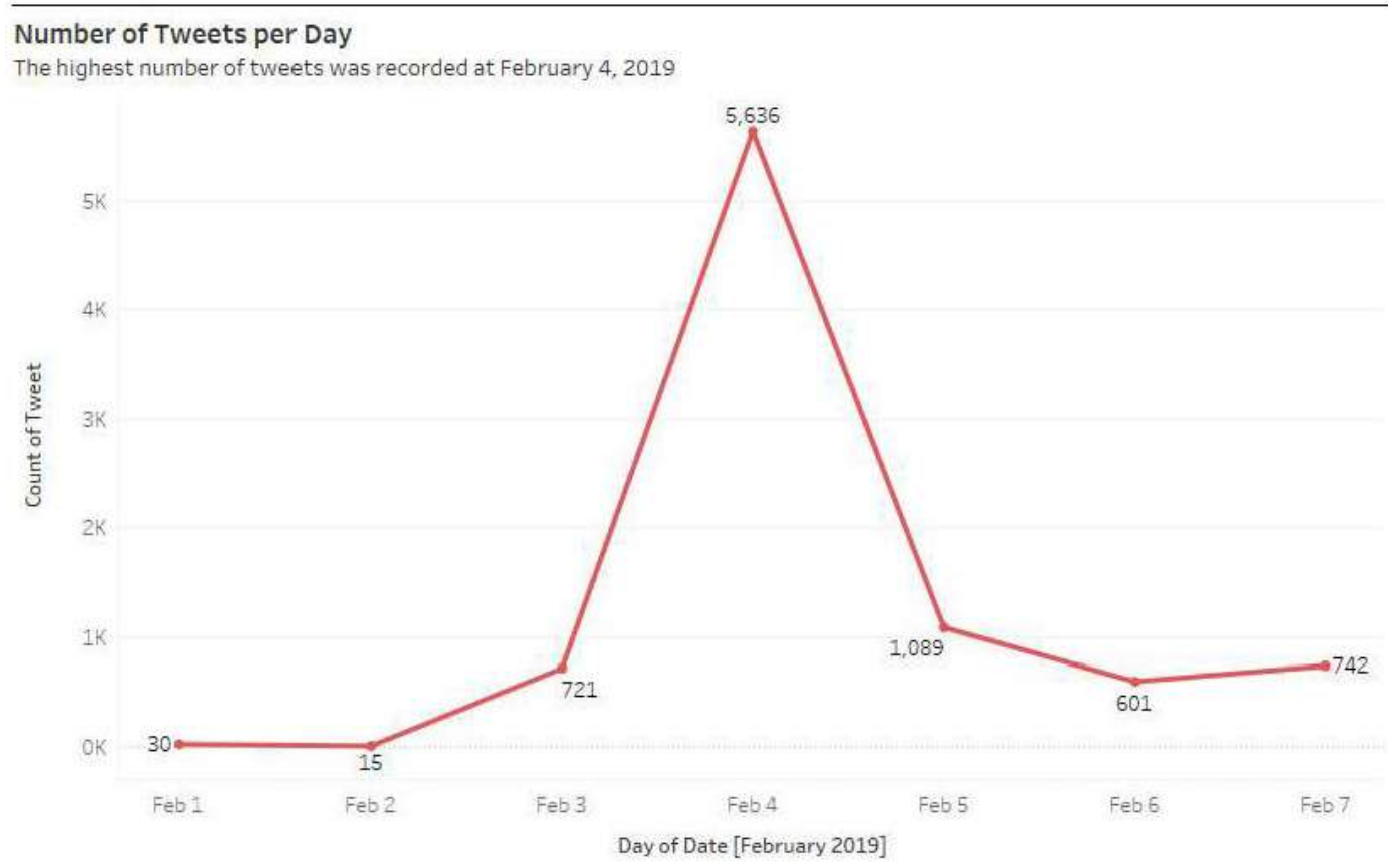

Figure 1. Number of Tweets Per Day

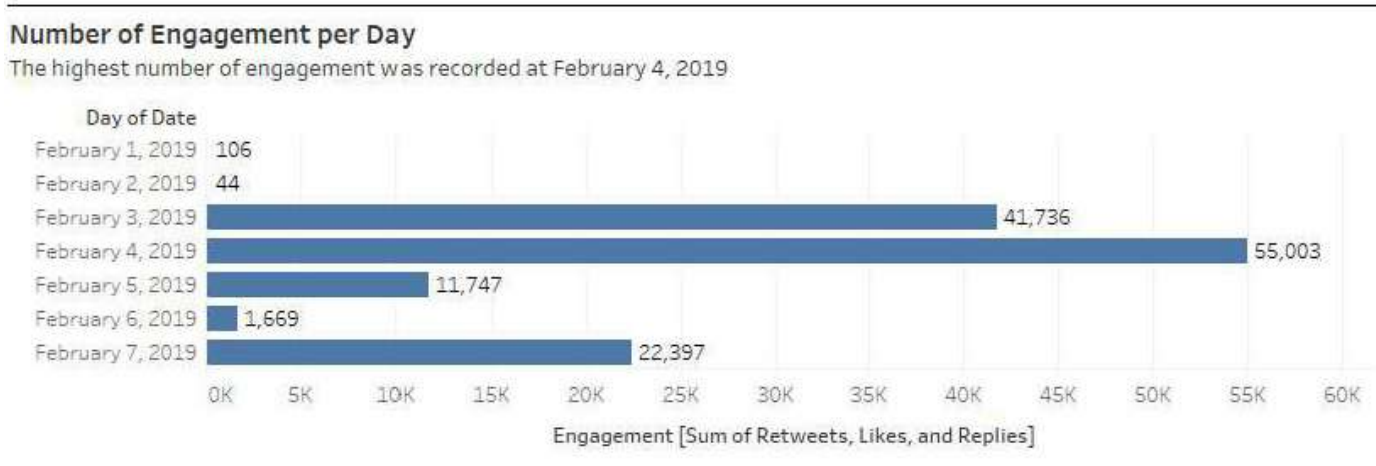

Figure 2. Number of Engagements Per Day

According to McAdam et al. (2001), we can consider a social movement as a success if the movement involved a scale shift. That would be the process whereby a small or local action becomes a significant social movement. It diffuses along pre-existing interaction lines and jumps through brokering into new, previously unconnected spheres (McAdam, Tarrow, \& Tilly, 2001; Tilly \& Tarrow, 2007). As seen in Figures 1 and 2, there is a significant scale shift on that day. The number of tweets and engagements during that time period shows that this social movement was not only brought by the artists, KNTL RUUP, or even mass media, but also by the ordinary people (public) that were involved in delivering their protests with this hashtag. 
Figure 2 shows the highest engagement was recorded on February 4, 2019. On that day, the number of replies reached 1,573 tweets; 28,620 tweets of retweets; and 24,810 likes. Not only that, the issue sparked discussion between users and influenced a broader amount of users in the form of Twitter engagements (replies, retweets, and likes), with a total number of 55,003 engagements. Based on the goals of this research, analyzing the movement, the volume of Twitter data mined by early February, the time period that filled the Twitter's traffic of its hashtag. The early days of this hashtag's traffic, January 29-31, 2019, was not used for the study because it showed only the pioneer who made this keyword into a hashtag. In addition, most of the data did not make \#TolakRUUPermusikan a social movement.

\section{Online Petition for Digital Advocacy}

According to the previous section, to prove the answer of the digital advocacy that was brought by \#TolakRUUPermusikan as a social movement, KNTL RUUP as a coalition has made an online petition to ask the public for the validation of this advocacy. Based on our research, an important finding about the effects of the construction of our social network analysis is an account called “@changeorg_id." The online petition platform provides a space for the public to participate in creating change (Hamid, 2015). In principle, the implementation of a public policy will have an impact on society (Lindner \& Riehm, 2011). A petition is a formal request to an authority that is usually co-signed by a group of supporters, and it has emerged to become a powerful tool for the public to make a positive impact on society (Noshokaty, Deng, \& Kwak, 2016). Public concern about the Music Bill issue was spread through online petitions and aimed to achieve policy action to thwart the issue. This illustrates the use of online petitions as a digital advocacy tool.

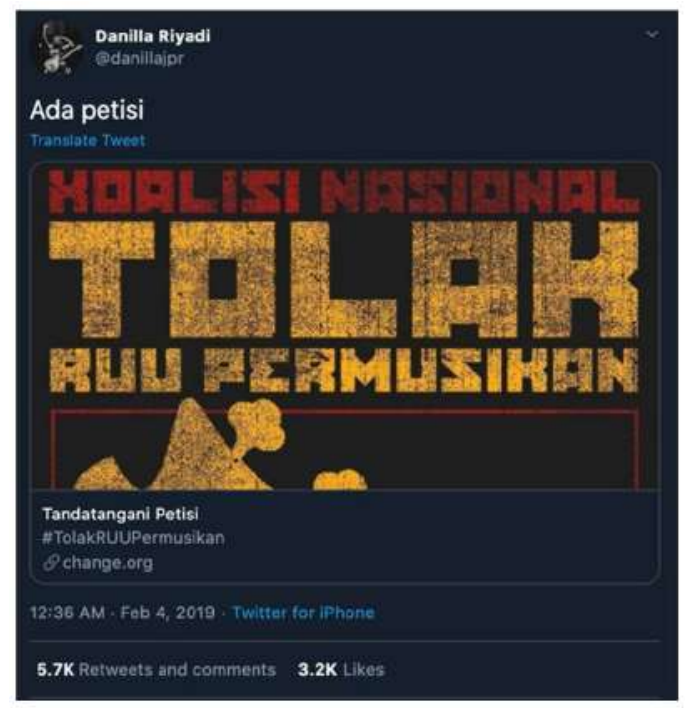

Figure 3. An Online Petition Shared by Actor 


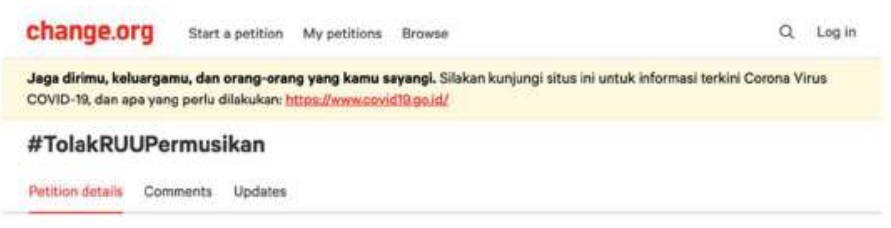

\#TolakRUUPermusikan
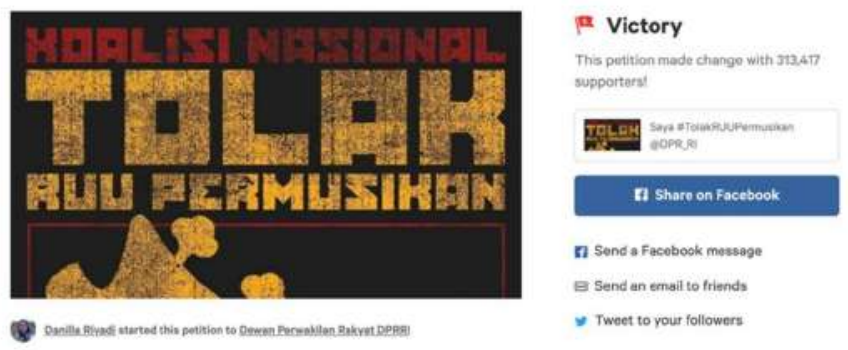

Figure 4. An Online Petition of \#TolakRUUPermusikan

One of the members of KNTLRUUP, a singer named Danilla Riyadi, a representative of the coalition of KNTLRUUP, was taking advantage of Change.org as the platform to mobilize the public by signing a petition that she made to tear down the draft bill. She posted the link of the petition on her Twitter that the researcher would attach in Figure 3. Based on Figure 3, we can see that Danilla Riyadi's tweet also made the traffic of \#TolakRUUPermusikan on February $4^{\text {th }}, 2019$, was increased and it was one of the reason why the scale shift in Figure 1 and 2 , on February $4^{\text {th }}$, was shifting dramatically. By seeing the Tweet itself, even though she did not put the keyword of \#TolakRUUPermusikan, it had driven the netizens on Twitter to sign the petition because of her fame as an artist and also made the "\#TolakRUUPermusikan" and "@changeorg_id" carried by her Tweet, that became viral and the traffic of this hashtag reached 5,636 Tweets, on February 4, 2019.

This online petition (Figure 4) is considered successful because it achieved the ultimate goal of encouraging policy action with the 313,417 supporters who signed the petition. Policy actions include the making, changing, or withdrawing of a policy. The ultimate goal of advocacy activities also includes policy implementation within government. However, this online petition fronted by Danilla Riyadi proved successful in bringing this petition to its original purpose as a form of rejection, and the petition has been notified by the policy maker (the House of Representatives), who has officially removed the Music Bill from the list of the National Priority Legislation Program (Prolegnas). The data discussed is successful in answering the first research question. 


\section{The Public's Voice in This Movement}

To find the context of the tweet, there are plenty of ways to display text data such as word cloud, semantic network analysis, and looking for tweets with the most engagements. Tweets need to be preprocessed in to obtain as much meaningful text information as possible. Data preprocessing is done by cleaning stop words and text lemmatizing. Both steps are preceded by tokenization or splitting the sentences into words. Stop words are not relevant in observing the main idea of a tweet or sentence; hence, stop word removal is an important step to get cleaner data. Removing prefixes and suffixes can be done by stemming or lemmatizing.

This is done to not confuse multiple forms of a single word as multiple, different words. The difference between stemming and lemmatizing is that stemming tends to find the base form of a word more aggressively using the computational algorithm. This often leads to misleading the interpretation of a word, or even error in figuring the word itself. Lemmatizing is a less aggressive way of finding the stem word, using both computational algorithm and a collection of stored dictionary of corpuses, as different forms of text often lead to different context, too (Muller \& Guido, 2017). This preprocessing phase uses the second method because of the nature of tweets, which uses a much more informal form of sentences or words.

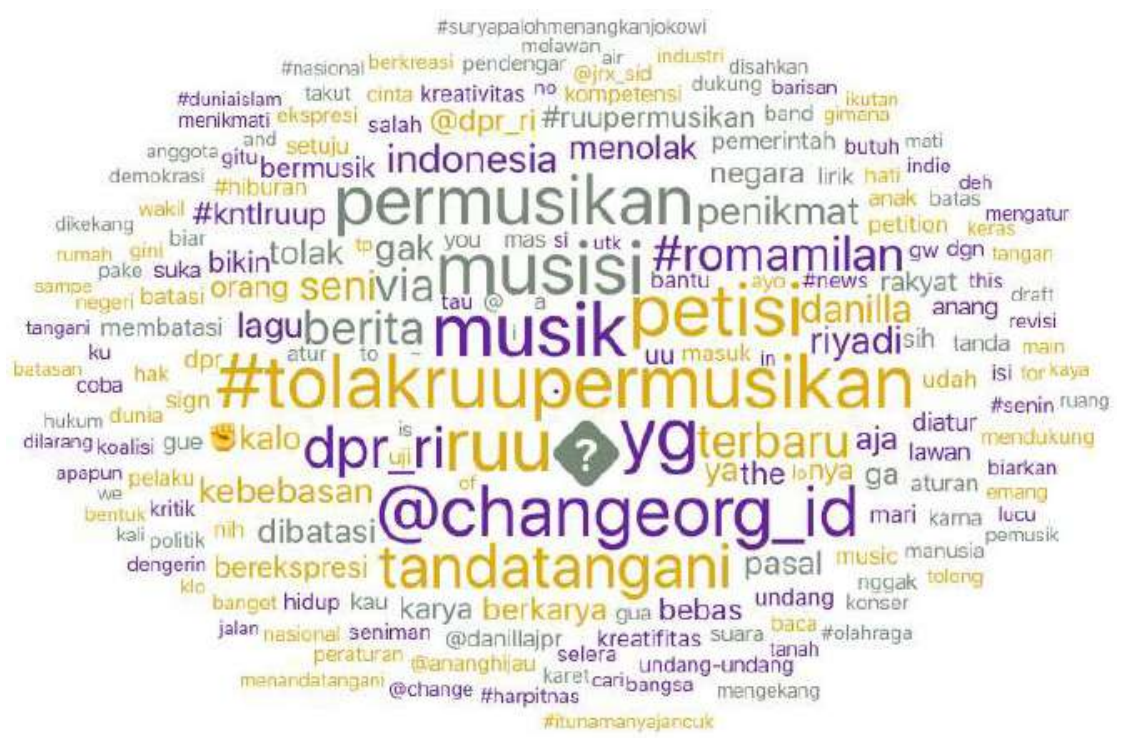

Figure 5. Word Cloud of Tweets' Engagement 


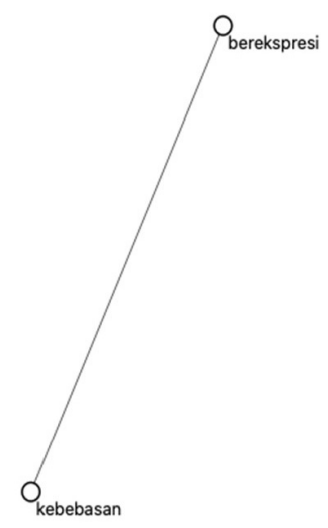

Figure 6. Semantic Network Graph Regarding the Critics to Music Draft Bill About the Freedom of Expression

After the data is cleaned, the most used words are displayed in a word cloud. Word clouds provide initial analyses on how the words might show context in a form of key information or expression (Bletzer, 2015). Figure 5 shows that the most words lead to invitation to fill out petition in change.org regarding to the \#TolakRUUPermusikan movement. Moreover, concern towards the possible violation in the right of expressionparticularly in music and art production-is also shown in corpuses such as "kebebasan" (freedom), "dibatasi" (repression), "membatasi" (limit), "kreativitas" (creativity), "berkarya" (creation), "berekspresi" (expression), and "bermusik" (playing music).

It is possible to look for a definitive context in some of the most mentioned words by using semantic network analysis (Drieger, 2013). It uses the same approach as network analysis by processing unstructured text data and by later defining words as nodes and the interconnectivity in sentences as edges. An edge or connectivity is formed if two words are used side-by-side; hence, a semantic relationship can be observed (Drieger, 2013).

The engagement formula that has been mentioned is able to unveil some of the most important tweets related to \#TolakRUUPermusikan. This study seeks to answer the research question on the public engagement to this case. From the several figures and graphs that have been shown above, we can see that the public engagement to this case is quite massive. In Figure 6, there is a unique structure in the social network analysis carried out by the researcher. This structure represents the word "kebebasan" (freedom) and the word "berekspresi" (expression). This section describes the notion of Twitter as social media that affects the freedom of expression of each user. We can conclude that the figures below show the linearity of public engagement through this movement. 


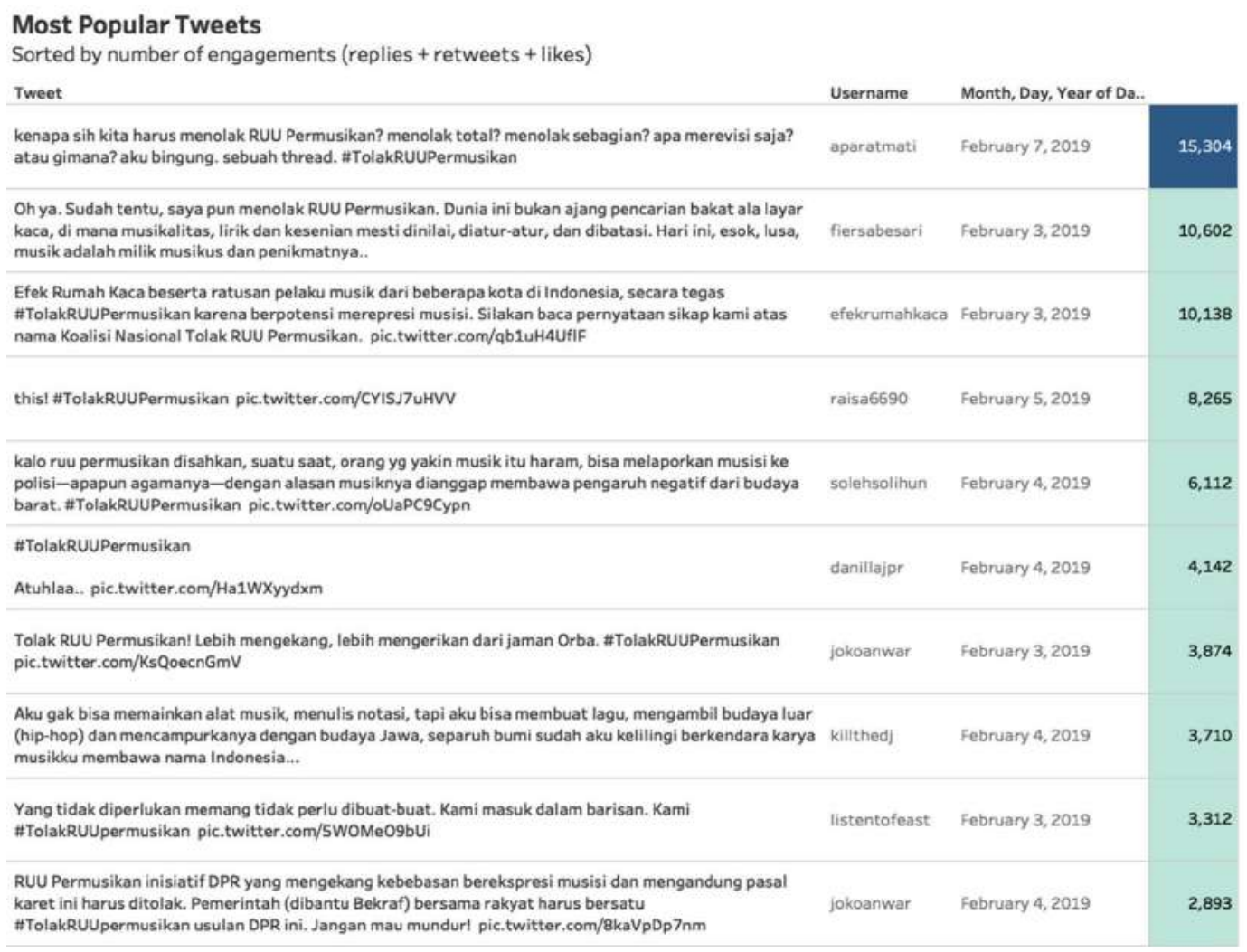

Figure 7. Top Ten Most Popular Tweets Sorted by Engagements

This figure shows general information on Twitter that can be observed by looking at tweets with the most engagement numbers. Figure 7 shows the top ten tweets with the most engagements. Every tweet in the top ten were posted in February 2019. Most of the tweets displayed, as far the top first tweet, lean towards informing the masses regarding the issue and the importance in supporting the movement by at the filling out an online petition form. The other tweets are from individuals showing solidarity in the movement, with no tweets from the other side of the spectrum gained such amount of engagements. From the figure above, several important individuals-mostly musicians and public figuresare shown as some of the most important pressure groups in regard to \#TolakRUUPermusikan as a social movement.

\section{Actors that Structured \#TolakRUUPermusikan in Twitter}

One of the ways of activism that stresses socialization of the group against the \#TolakRUUPermusikan, is the actors behind this social movement, who have also used Twitter as a media to deliver their arguments against the bill with the purpose of influencing public opinion. In its delivery they mobilized this as a form of social movement. In accordance with the question, "Who are the actors behind \#TolakRUUPermusikan?" 
in this last section the researcher analyzes the actors behind this social movement. In this segment, we examine how the network, based on followers, likes, retweets, and posts on Twitter, can be built through trend analysis according to the accounts that has the most influence in \#TolakRUUPermusikan movement.

Table 2. Top 10 Actors on \#TolakRUUPermusikan

\begin{tabular}{|c|c|c|c|c|c|c|}
\hline No. & Username & Followers & Retweet & Likes & Replies & Tweet \\
\hline 1. & @aparatmati & 95662 & 19091 & 17114 & 736 & 167 \\
\hline 2. & @efekrumahkaca & 231179 & 9600 & 5007 & 167 & 4 \\
\hline 3. & $@$ kntlruup & 1311 & 5038 & 5018 & 104 & 173 \\
\hline 4. & @fiersabesari & 5243410 & 4828 & 5648 & 126 & 1 \\
\hline 5. & @jokoanwar & 1778272 & 3893 & 3222 & 111 & 3 \\
\hline 6. & @solehsolihun & 401455 & 3828 & 3438 & 106 & 3 \\
\hline 7. & @raisa6690 & 8859684 & 3014 & 5064 & 187 & 1 \\
\hline 8. & @seringai & 187465 & 2477 & 1562 & 37 & 4 \\
\hline 9. & @danillajpr & 437883 & 2219 & 1852 & 71 & 1 \\
\hline 10. & $@$ listentofeast & 44225 & 2029 & 1817 & 32 & 4 \\
\hline
\end{tabular}

The results of the listed 10 users has shown that actors who come from different backgrounds have the most significant influence on the \#TolakRUUPermusikan. The account in Table 2 impacts the construction of the social network that was created on Twitter in \#TolakRUUPermusikan due to the broad impact on-post from the distribution of tweets, and also from likes and retweets. The actor with the most influence on Twitter's \#TolakRUUPermusikan is Arian Arifin, known on Twitter as "@aparatmati" a vocalist from a hard-rock Indonesian band named Seringai. Arian Arifin has posted 167 tweets of content that uses \#TolakRUUPermusikan. The number of followers also influences the tweets exchanged with other accounts on the network. The link between \#TolakRUUPermusikan 's 10 powerful actors to the network structure is the amount of interaction with other actors that can be measured via the centrality network, that we can see below in Figure 8. 


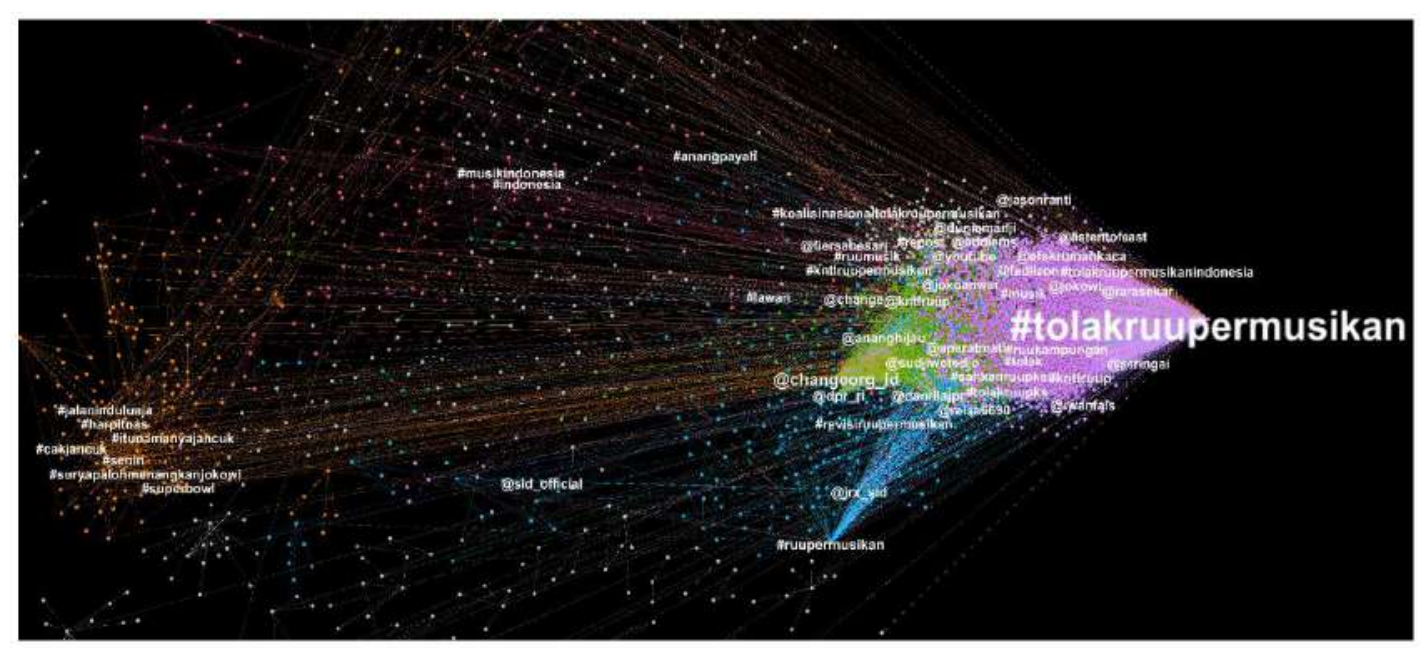

Figure 8. Mentions and Hashtags Social Network Analysis

In figure 8, actor-based analysis was conducted using social network analysis (SNA). SNA is able to visualize a connection between actors-not only the most important onesbut also every user that is detected through engagements in provided data-in a form of nodes and edges (Chen, et al., 2008). Computational calculation in SNA can be observed both visually and by using statistical data such as degree and centrality (Himelboim, 2017).

Based on Figure 8, the SNA has shown the most mentioned account regarding the issue, which consists of change.org and DPR RI accounts. DPR RI as the main actor of the Music Draft Bill was confronted directly on social media, by seeing that the other actors were mostly artists from the Indonesian music industry. Figure 8 shows that a cluster on the left side of the hashtag is mostly dominated by artists and musicians who posted the tweets about \#TolakRUUPermusikan. As the group that will be affected the most while also having a high amount of social media exposure, it comes as no surprise. 
Table 3. Centrality Network of 10 Top Actors

\begin{tabular}{llcccccc}
\hline No & Username & $\begin{array}{c}\text { In- } \\
\text { degree }\end{array}$ & $\begin{array}{c}\text { Out- } \\
\text { degree }\end{array}$ & Degree & $\begin{array}{c}\text { Closeness } \\
\text { Centrality }\end{array}$ & $\begin{array}{c}\text { Betweenness } \\
\text { Centrality }\end{array}$ & $\begin{array}{c}\text { Eigenvector } \\
\text { Centrality }\end{array}$ \\
\hline 1 & @changeorg_id & 1012 & 0 & 1012 & 0 & 0 & 0.14886 \\
2 & @dpr_ri & 316 & 0 & 316 & 0 & 0 & 0.046486 \\
3 & @danillajpr & 139 & 1 & 140 & 1 & 0 & 0.020469 \\
4 & @jrx_sid & 107 & 0 & 107 & 0 & 0 & 0.015738 \\
5 & $@$ @ananghijau & 92 & 0 & 92 & 0 & 0 & 0.013532 \\
6 & @efekrumahkaca & 71 & 2 & 73 & 1 & 0.000001 & 0.010443 \\
7 & @change & 50 & 0 & 50 & 0 & 0 & 0.007354 \\
8 & @aparatmati & 47 & 10 & 57 & 0.527273 & 0.000019 & 0.006998 \\
9 & @kntlruup & 32 & 16 & 48 & 0.690476 & 0.000023 & 0.004824 \\
10 & @fiersabesari & 28 & 1 & 29 & 1 & 0 & 0.004118 \\
\hline
\end{tabular}

The size of the spread and magnitude of the effect of one account on another account can be shown by the results of our analysis (Figure 8) of the central network involving the three most important network components, namely the actor's centrality based in-degree, betweenness, and eigenvector, which can be seen in Table 3. In-degree centrality measures how much a node is targeted with messages (and @mentions) and is typically used to make a network significant (Hanneman \& Riddle, 2005). Betweenness centrality measures the frequency at which a single node lies on the shortest path that links other nodes in the network (Liu, Sidhu, \& Valente, 2017). Eigenvector centrality not only considers overall connections but also connections to other relevant nodes (Hanneman \& Riddle, 2005). In this analysis, the intensity or consistency of the ties between network members will be assessed (Arnold, 2011).

Its connection between 10 prominent actors of the \#TolakRUUPermusikan movement to the network structure is the amount of interaction with other actors that can be measured via the centrality network. In addition, they were mostly artists and musicians, who have a large number of followers. The greater the number in each group, the greater the distribution of other links for the three central network measurements. Generally, accounts with a high degree of centrality seem more likely to become opinion leaders (Liu, Sidhu, \& Valente, 2017). However, we can see how those actors positioned themselves in the discourse map, by looking at the in- and out-degree numbers. Accounts with a zero outdegree number mostly were subjected as the pressured group, such as @dpr_ri and @ananghijau, as a part of the parliament. On the other hand, accounts like @kntlruup and @aparatmati led the number of out-degree. They were actively involved in, not only 
engaging with the issue, but also tweeting, expressing their stance, and protesting against the Music Draft Bill.

The creation of a set of relations of the network to nodes can be seen from the total value of betweenness centrality. Measurement of the number of sets of relations of the network against other actors can be achieved through a scale of 0-1 on the results of betweenness centrality. Through these numbers the research concluded that the structure of the network developed to other actors. Additionally, actors such as @efekrumahkaca, @aparatmati, and @kntlruup who not only reported with out-degree numbers but also in-degree numbers have their betweenness number above 0 . This shows that apart from being a pure opinion leaders, they also acted as intermediary figures in the dialogue between two separate groups.

Finally, closeness centrality can be defined as a node that compares its average farness to all other nodes. When increasing the number in the proximity centrality, it can be inferred that the account contributes to the network spreading established from one account to the other. With the analysis and results of the centrality network measurement on the ten most prominent accounts in the \#TolakRUUPermusikan movement, we can infer that the network created in that movement is also influenced by a huge amount of message propagation to one account to another.

\section{CONCLUSION}

This research has found that the public reaction to a hashtag-based feature such as \#TolakRUUPermusikan (that was born organically by ordinary people) can become a social movement. This movement has successfully impacted the agenda setting and policy formulation process of The House of Representatives. The findings in this study has clarified key points in a hashtag affiliated movement: the social movement that was applied to digital advocacy in the form of protest, the actors behind the \#TolakRUUPermusikan movement on Twitter, and the public engagement through this movement. The research finding suggest that every actor has a role to play in contributing to the movement including education, being a source of criticism, becoming a source of information, expanding news, and allocating resources. In addition, by exploring the overall content of \#TolakRUUPermusikan Tweets on Twitter and the supporting factors in spreading the message through trend analysis on influential actors, this study has researched how the hashtag was formed by social network data analysis. Looking at the results of classifying messages on Twitter's \#TolakRUUPermusikan, we found facts in the community's response to this campaign that dominated critique of the government's decision through this Music Draft Bill. We have found in our social network analysis that the structure of networks is affected by influential actors who have a strong engagement with other accounts based on various factors such as likes and retweets, through their protests. 
As a result, the major limitation of this study is how we take an in-depth analysis of the structure of social networks by using other measurements in the analysis of social networks that required a great amount of data. Whilst having this research analyzing the network structure in the \#TolakRUUPermusikan movement, researchers discovered that there are actors who can play a major role in this social movement as well as how these actors correlate with other emerging issues. Meanwhile, on the government side, which is also categorized as the actor behind this policy, we didn't find any response from the government, DPR RI, towards Music Draft Bill.

The implication of this study suggests that the importance of involving various stakeholders to address public policy problems which is complicated in nature. Therefore, a multi-stakeholder partnership is crucial because by mobilizing many stakeholders in the public policy process, it promotes a participatory approach that encourages a dialogue to improve the quality of the decision making process and supports successful government policy formulation.

\section{REFERENCES}

Afifiyah, S. (2019, February 6). Anang Cerita Awal Mula Gagasan RUU Musik. Retrieved April 26, 2019, from Tagar News: https://www.tagar.id/anang-cerita-awal-mulagagasan-ruu-musik

Almog-Bar, M., \& Schmid, H. (2014). Advocacy activities of nonprofit human service organizations: A critical review. Nonprofit and Voluntary Sector Quarterly, 43(1), 1135.

Arnold, G. (2011, April 1). The Impact of Social Ties on Coalition Strength and Effectiveness: The Case of the Battered Women's Movement in St Louis. Social Movement Studies, 10, 131-150.

Barassi, V. (2015). Social media, immediacy and the time for democracy: Critical reflections on social media as 'Temporalizing Practices'. In L. Dencik, \& O. L. (Eds.), Critical perspec- tives on social media and protest: Between control and emancipation. London: Rowman \& Littlefield.

Barisione, M., Michailidou, A., \& Airoldi, M. (2017). Understanding a digital movement of opinion: the case of \#RefugeesWelcome. Information, Communication $\mathcal{E}$ Society, 120.

Bletzer, K. (2015). Visualizing the qualitative: making sense of written comments from an evaluative satisfaction survey. Journal of Educational Evaluation for Health Professions(12), 12.

Bruns, A., \& Burgess, J. (2011). The Use of Twitter Hashtags in the Formation of Ad Hoc Publics. Paper presented at the 6th European Consortium for Political Research General Conference. 
Burgess, J. (2011, June 8). "A (Very) Short History of Social Media Taglines.". Retrieved from Creativity/Machine: http:/ / creativitymachine.net/2011/06/08/a-very-shorthistory-of-social-media-taglines/

Castells, M. (2012). Networks of outrage and hope: Social movements in the internet age. . Malden, MA: Polity Press.

Chadwick, A. (2013). The Hybrid Media System: Politics and Power. Oxford: Oxford University Press.

Chadwick, A., \& Howard, P. N. (2009). Routledge Handbook of Internet Politics. New York: Routledge Taylor \& Francis Group.

Chen, S., Ross, T. J., Zhan, W., Myers, C. S., Chuang, K.-S., Heishman, S. J., . . Yang, Y. (2008). Group independent component analysis reveals consistent resting-state networks across multiple sessions. Brain Research, 1239, 141-151.

Cherven, K. (2015). Mastering Gephi network visualization: Produce advanced network graphs in Gephi and gain valuable insights into your network datasets. Birmingham: Packt Pub.

Crossley, N. (2016). Networks, Interaction, and Conflict: A Relational Sociology of Social Movements and Protest. Social Theory and Social Movements, 155-173.

Dewan Perwakilan Rakyat Indonesia. (2018, Agustus 15). RANCANGAN UNDANGUNDANG REPUBLIK INDONESIA NOMOR $\ldots$ TAHUN $\ldots$ TENTANG PERMUSIKAN. Jakarta, DKI Jakarta, Indonesia.

Drieger, P. (2013). Semantic Network Analysis as a Method for Visual Text Analysis. Procedia - Social and Behavioral Sciences(4), 17.

Dunlop, J. M., \& Fawcett, G. (2008). Technology-based approaches to social work and social justice. . Journal of Policy Practice, 7(2-3), 140-154.

Earl, J. (2015). CITASA: Intellectual past and future. Information, Communication $\mathcal{E}$ Society., 18, 478-491.

Earl, J., \& Rohlinger, D. A. (2012). Introduction: Media, movements, and political change. . Research in Social Movements, Conflicts and Change., 1-13.

FitzGerald, E., \& McNutt, J. G. (1999). Electronic advocacy in policy practice: A framework for teaching technologically based practice. . Journal of Social Work Education, 35(3), 331- 341.

Fotaki, M. (2010). Why do public policies fail so often? Exploring health policy-making as an imaginary and symbolic construction.

Gamson, W. A. (1992). Talking politics. Cambridge: Cambridge University Press.

Ghali, N., Panda, M., Hassanien, A. E., Abraham, A., \& Snasel, V. (2012). Social Networks Analysis: Tools, Measures and Visualization. Computational Social Networks: Mining and Visualization, 1.

Ginneken, J. V. (2003). Collective behaviour and public opinion - Rapid shifts in opinion and communication. Mahwah, NJ: Erlbau. 
Greenberg, J., \& MacAulay, M. (2009). NPO 2.0? Exploring the web presence of environmental nonprofit organizations in Canada. Global Media Journal-Canada Edition, 2(1), 63-88.

Guo, C., \& Saxton, G. D. (2014). Tweeting social change: How social media are changing nonprofit advocacy. Nonprofit Voluntary Sector Quarterly, 43(1), 57-79.

Hamid, U. (2015). Digital Nation Movement: Dinamo. Jakarta: Bentang Pustaka.

Hanneman, R. A., \& Riddle, M. (2005). Introduction to social network methods. Riverside, CA: University of California Riverside.

Himelboim, I. (2017). Social Network Analysis (Social Media). The International Encyclopedia of Communication Research Methods, 1-15.

Himelboim, I., McCreery, S., \& Smith, M. (2013). Birds of a Feather Tweet Together: Integrating Network and Content Analyses to Examine Cross Ideology Exposure on Twitter. Journal of Computer-Mediated Communication, 154-174.

Himelboim, I., Smith, M. A., Rainie, L., Shneiderman, B., \& Espina, C. (2017). Classifying Twitter Topic-Networks Using Social Network Analysis. Social Media + Society(https:/ /doi.org/10.1177/2056305117691545).

Hoefer, R. (2012). Advocacy practice for social justice. Chicago: Lyecum.

Imhonopi, D., Onifade, C. A., \& Urim, U. M. (2013). Collective Behaviour and Social Movements:a Conceptual Review. Research on Humanities and Social Sciences, 3(10).

Jansson, B. (1994). Social Policy: From Theory to Policy Practice. Belmont, CA: Brooks/ Cole.

Jin, Y. (2017). Development of Word Cloud Generator Software Based on Python. Procedia Engineering, 788-792.

Johansson, H., \& Scaramuzzino, G. (2019). The logics of digital advocacy: Between acts of political influence and presence. New Media E Society, 21(7), 1528-1545.

Karaduman, H. (2012). Usage of Social Media by Political Actors: An Analysis on the Usage of Twitter by Leaders of Political Parties in Turkey. Journal of Medianali, 6(12), 2-13.

Kaun, A. (2016). Crisis and critique: A brief history of media participation in times of crisis. London: Zed Books Ltd.

Knibbs, K. (2013, May 15). Slacktivists UNITE! Social media campaigns aren't just feel - good back patting. Retrieved from Digital Trends: http://www.digitaltrends.com/ socialmedia/slacktivists-unite-social-media-campaigns-arent-just-feel-goodbackpatting/

Koc-Michalska, K., Lilleker, D., \& Vedel, T. (2016). Civic political engagement and social change in the new digital age. New Media and Society, 18(9), 1807-1816.

Kolb, F. (2007). Protest and opportunities: The political outcomes of social movements. Frankfurt: Campus Verlag. 
Kusche, I. (2016). Social Movements and Sociological Systems Theory. Social Theory and Social Movements, 75-91.

Kusumasari, B., \& Kusumaningrum, H. (2019). Application of the Resource Mobilization Theory in Indonesia's Environmental Movements. Journal of Comparative Asian Development, 17(2), 78-98.

Lindner, R., \& Riehm, U. (2011). Broadening Participation Through E-Petitions? An Empirical Study of Petitions to the German Parliament. Policy \& Internet, 3(1), 1-23.

Liu, W., Sidhu, A. B., \& Valente, T. W. (2017). Social Network Theory. The International Encyclopedia Of Media Effects, 4.

Lovejoy, K., Waters, R. D., \& Saxton, G. D. (2012). Engaging stakeholders through Twitter: How nonprofit organizations are getting more out of 140 characters or less. Public Relations Review, 38 , 313-318.

Mahmud, C. (2019, February 12). Bukan RUU Permusikan, Tapi RUU Sertifikasi Musisi. Retrieved April 26, 2019, from Tirto.id: https://tirto.id/bukan-ruu-permusikan-tapiruu-sertifikasi-musisi-dgG4

Manalu, D. (2007). Kasus Perlawanan Masyarakat Batak vs PT. Indi Indorayon Utama, di Porsea, Sumatera Utara. Gerakan Sosial dan Perubahan Kebijakan Publik, 27-50.

McAdam, D., Tarrow, S. G., \& Tilly, C. (2001). Dynamics of contention. New York, NY: Cambridge University Press.

McNutt, J. (2011). Is social work advocacy worth the cost? Issues and barriers to an economic analysis of social work political practice. Research on Social Work Practice, 21(4), 397- 403.

Melucci, A. (1996). Challenging codes: Collective action in the information age. . Cambridge: Cambridge University Press.

Merrill, S., \& Lindgren, S. (2018). The rhythms of social movement memories: The mobilization of Silvio Meier's activist remembrance across platforms. . Social Movement Studies, 1-18.

Messina, C. (2007, August 25). "Groups for Twitter; or A Proposal for Twitter Tag Channels." . Retrieved from FactoryCity: http:/ / factoryjoe.com/blog/2007/08/25/groups-fortwitter-or-a-proposal-for-twitter-tag-channels /

Millward, P., \& Takhar, S. (2019). Social Movements, Collective Action and Activism. Sociolgy, 1-12.

Muller, A., \& Guido, S. (2017). Introduction to Machine Learning with Phyton. Sebastopol: O’Reilly Media.

Noshokaty, A. E., Deng, S., \& Kwak, D.-H. K. (2016). Success Factors of Online Petitions: Evidence from Change.org. Hazaii International Conference on System Sciences, 19791985. 
Ostlund, U., Kidd, L., Wengstrom, Y., \& Rowa-Dewar, N. (2010). Combining qualitative and quantitative research within mixed method research designs: A methodological review. International Journal of Nursing Studies, 1-3.

Perwitasari, N. H. (2019, February 3). 260 Musisi Nyatakan Menolak RUU Permusikan. Retrieved April 26, 2019, from Tirto.id: https:/ / tirto.id/260-musisi-nyatakan-menolakruu-permusikan-dfPj

Petrick, K. (2017). Occupy and the temporal politics of prefigurative democracy. tripleC: Communication, Capitalism \& Critique. Open Access Journal for a Global Sustainable Information Society, 15(2), 490-504.

Poell, T. (2019). Social media, temporality, and the legitimacy of protest. Social Movement Studies, 1-16.

Porta, D. d., \& Diani, M. (1999). Social movements: An introduction. Oxford: Blackwell.

Robert, R. E., \& Kloss, R. M. (1979). Social Movement Between the Balcony and the Barricade. America: Mosby Company.

Rusmanto, J. (2012). GERAKAN SOSIAL: Sejarah Perkembangan Teori Antara kekuatan dan Kelemahannya. Palangkaraya: Zifatama Publishing.

Saunders, C. (2007). Using social network analysis to explore social movements: A relational approach. Social Movement Studies, 6(3), 227-243.

Saxton, G. D., Niyirora, J. N., Guo, C., \& Waters, R. D. (2015). \#AdvocatingForChange: The Strategic Use of Hashtags in Social Media Advocacy. Advances in Social Work, 154-169.

Schoech, D. (2013). Community practice in the digital age. In M. Weil, M. Reisch, \& M. L. Ohmer, The handbook of community practice (pp. 809-826). Thousand Oaks, CA: SAGE. Sills, D. L. (1968). International encyclopedia of the social sciences. (Vol. 14). United States of America: The Macmillan Company and the Free Press.

Silva, E. (2015). Social Movements, Protest, and Policy. Revista europea de estudios latinoamericanos y del Caribe $=$ European review of Latin American and Caribbean studies, 27-39.

Simply Measured. (2014). How to Analyze the Metrics that Matter. The Complete Guide to Twitter Analytics.

Smit, R., Heinrich, A., \& Broersma, M. (2018). Activating the past in the Ferguson protests: Memory work, digital activism and the politics of platforms. New Media $\mathcal{E}$ Society, 20(9), 3119-3139.

Steinberg, S. B. (2016). \#Advocacy: Social Media Activism's Power to Transform Law. Kentucky Law Journal, 105(3).

Stelekenburg, J. v. (2013). Collective identity. The Wiley-Blackwell Encyclopedia of Social and Political Movements, 1-7. 
Taylor, V., \& Whittier, N. (1992 ). Collective identity in social movement communities: Lesbian feminist mobilization. In A. Morris, \& C. Mueller, Frontiers of Social Movement Theory. . New Haven, CT: Yale University Press.

Tilly, C., \& Tarrow, S. G. (2007). Contentious politics. Boulder, CO: Paradigm Publishers. Wardhani, A. K. (2019, March 8). Tarik Draft UU Permusikan, Anang Hermansyah Singgung Pendapatan dari YouTube Artikel ini telah tayang di Tribunnews.com dengan judul Tarik Draft UU Permusikan, Anang Hermansyah Singgung Pendapatan dari YouTube. Retrieved April 2019, from http://www.tribunnews.com/seleb/2019/03/08/tarik-draft-uupermusikan-anang-hermansyah-singgung-pendapatan-dari-youtube

Waters, R. D., Burnett, E., Lamm, A., \& Lucas, J. (2009). Engaging stakeholders through social networking: How nonprofit organizations are using Facebook. Public Relations Review, 35, 102-106.

Wesley, R., Eldridge, M., \& Terlecki, P. (2011). An Analytic Data Engine for Visualization in Tableau. Proceedings of the 2011 International Conference on Management of Data SIGMOD '11. doi:10.1145/1989323.1989449, 1185-1193.

Yin, R. K. (2009). Case Study Research: Design and Methods. Thousand Oaks, CA: Sage. Thousand Oaks, California: Sage.

\section{ACKNOWLEDGEMENT}

Muhammad Ananda Alifiarry as the author, would like to thank to Allah SWT (God Almighty) and Ario Setra Setiadi, Drs., M.M., Ph.D, CPM., DipM, ACIM., CHRM., Bella Agustuti, S.T., Emmanuel Pradipta, S.IP., Karina Ramadhanty Budiman, S.IP., Karunia Saputra Hidayat, S.E., Muhammad Rifqi Satria, Muhammad Riga Pratama, Rahmat Putra Perdana Marsaoli, S.IP., Warih Aji Pamungkas, S.T., Dr. Wuryantari Setiadi, M.Si, for their mental support, review, and thoughtful comments. 